Article

\title{
Evaluating Summer-Time Ozone Enhancement Events in the Southeast United States
}

\author{
Matthew S. Johnson ${ }^{1}{ }^{*}$, Shi Kuang ${ }^{2}$, Lihua Wang ${ }^{2}$ and M. J. Newchurch ${ }^{3}$ \\ 1 Earth Science Division, NASA Ames Research Center, Moffett Field, CA 94035, USA \\ 2 Earth System Science Center, University of Alabama in Huntsville, Huntsville, AL 35899, USA; \\ kuang@nsstc.uah.edu (S.K.); lihuawang@nsstc.uah.edu (L.W.) \\ 3 Atmospheric Science Department, University of Alabama in Huntsville, Huntsville, AL 35899, USA; \\ mike@nsstc.uah.edu \\ * Correspondence: matthew.s.johnson@nasa.gov; Tel.: +1-650-604-5420
}

Academic Editor: Robert W. Talbot

Received: 11 July 2016; Accepted: 16 August 2016; Published: 19 August 2016

\begin{abstract}
This study evaluates source attribution of ozone $\left(\mathrm{O}_{3}\right)$ in the southeast United States (US) within $\mathrm{O}_{3}$ lamina observed by the University of Alabama in Huntsville (UAH) Tropospheric Ozone Lidar Network (TOLNet) system during June 2013. This research applies surface-level and airborne in situ data and chemical transport model simulations (GEOS-Chem) in order to quantify the impact of North American anthropogenic emissions, wildfires, lightning $\mathrm{NO}_{\mathrm{x}}$, and long-range/stratospheric transport on the observed $\mathrm{O}_{3}$ lamina. During the summer of 2013, two anomalous $\mathrm{O}_{3}$ layers were observed: (1) a nocturnal near-surface enhancement and (2) a late evening elevated (3-6 km above ground level) $\mathrm{O}_{3}$ lamina. A "brute force" zeroing method was applied to quantify the impact of individual emission sources and transport pathways on the vertical distribution of $\mathrm{O}_{3}$ during the two observed lamina. Results show that the nocturnal $\mathrm{O}_{3}$ enhancement on 12 June 2013 below $3 \mathrm{~km}$ was primarily due to wildfire emissions and the fact that daily maximum anthropogenic emission contributions occurred during these night-time hours. During the second case study it was predicted that above average contributions from long-range/stratospheric transport was largely contributing to the $\mathrm{O}_{3}$ lamina observed between 3 and $6 \mathrm{~km}$ on 29 June 2013. Other models, remote-sensing observations, and ground-based/airborne in situ data agree with the source attribution predicted by GEOS-Chem simulations. Overall, this study demonstrates the dynamic atmospheric chemistry occurring in the southeast US and displays the various emission sources and transport processes impacting $\mathrm{O}_{3}$ enhancements at different vertical levels of the troposphere.
\end{abstract}

Keywords: ozone; air quality; source attribution; TOLNet Lidar

\section{Introduction}

Ozone $\left(\mathrm{O}_{3}\right)$ is an atmospheric pollutant that can have negative impacts on the environment and human health [1]. Additionally, $\mathrm{O}_{3}$ acts as a greenhouse gas influencing Earth's radiative balance and surface temperatures [2]. Ozone is a key component in air quality and surface-level mixing ratios are strictly enforced by the United States (US) Environmental Protection Agency (EPA) under the National Ambient Air Quality Standards (NAAQS). The NAAQS set in 2015 requires that 3 year averages of the annual fourth-highest daily maximum 8 hour mean mixing ratio be less than or equal to $70 \mathrm{nmol} \mathrm{mol}^{-1}$ with future plans of lowering this value even further [3]. As NAAQS values continue to be lowered, it becomes increasingly important to understand emission sources, chemical processes, and transport pathways which are primarily controlling tropospheric $\mathrm{O}_{3}$ and exceedance events of surface-level air quality standards. 
Tropospheric $\mathrm{O}_{3}$ is predominantly produced by the downward transport from the stratosphere and the photochemical oxidation of carbon monoxide $(\mathrm{CO})$, methane $\left(\mathrm{CH}_{4}\right)$, and other volatile organic compounds (VOCs) by nitrogen oxides $\left(\mathrm{NO}_{\mathrm{x}}=\right.$ nitric oxide and nitrogen dioxide $\left.\left(\mathrm{NO}+\mathrm{NO}_{2}\right)\right)$ (e.g., [4,5]). Stratospheric air is transported to the troposphere, commonly referred to as stratosphereto-troposphere transport, and can largely contribute to the mixing ratios and vertical structure of $\mathrm{O}_{3}$ in the troposphere (e.g., [6-9]). Stratospheric transport of $\mathrm{O}_{3}$ is particularly important for rural locations in the higher elevations of the US such as the Intermountain West (e.g., [9,10]). Precursor gases leading to $\mathrm{O}_{3}$ formation/destruction (e.g., $\mathrm{CO}, \mathrm{CH}_{4}, \mathrm{VOCs}$, and $\mathrm{NO}_{\mathrm{x}}$ ) in the troposphere are emitted from anthropogenic sources (e.g., fossil fuel combustion, vehicle emissions), wildfires and biomass burning, and natural sources (e.g., lightning $\mathrm{NO}_{\mathrm{x}}$, soils, and vegetation). The southeast US is a unique region which is largely impacted by all the aforementioned sources of $\mathrm{O}_{3}$ and precursor gas emissions [11]. The numerous sources of $\mathrm{O}_{3}$ and precursor gases and complex atmospheric chemistry controlling the air quality of the southeast US is currently of large scientific interest which has led to multiple measurement campaigns focused on aerosol and trace gas concentrations during the summer months (e.g., Southern Oxidant and Aerosol Study (SOAS), Studying the Interactions Between Natural and Anthropogenic Emissions at the Nexus of Climate Change and Air Quality (SENEX), and Studies of Emissions and Atmospheric Composition, Clouds and Climate Coupling by Regional Surveys (SEAC $\left.{ }^{4} \mathrm{RS}\right)$ ).

Due to the complex nature of air quality in the southeast US, chemical transport model (CTM) simulations and measurement data are necessary to better understand and reproduce the spatio-temporal variability of $\mathrm{O}_{3}$ mixing ratios. Model simulations are also necessary to evaluate and quantify the impact of individual emissions sources, transport pathways, and chemistry/deposition processes on observed $\mathrm{O}_{3}$ mixing ratios. However, individual CTMs have demonstrated varying ability to replicate measured $\mathrm{O}_{3}$ in the southeast US (e.g., $\left.[4,12,13]\right)$. Therefore, in situ and remote-sensing data are necessary to evaluate models in order to understand the ability of an individual model to reproduce $\mathrm{O}_{3}$ and precursor species. Numerous networks of ground-based in situ measurement sites are located in the southeast US (e.g., SouthEastern Aerosol Research and Characterization (SEARCH) Network, EPA Air Quality System (AQS), etc.), however, limited continuous data sources have in the past been available to constrain model-predicted vertical $\mathrm{O}_{3}$ profiles. To provide information on the vertical structure of $\mathrm{O}_{3}$ in the troposphere in various locations of the US the NASA/NOAA Tropospheric Ozone Lidar Network (TOLNet) [14] was developed. During the summer of 2013 the TOLNet lidar located at the University of Alabama in Huntsville (UAH) observed multiple days in which large $\mathrm{O}_{3}$ lamina occurred. During this study, in order to investigate the anthropogenic and natural sources contributing to these anomalous $\mathrm{O}_{3}$ layers measured during June 2013, we apply the three-dimensional (3D) CTM GEOS-Chem and ground-based/airborne in situ measurement data.

\section{Methods}

\subsection{TOLNet Ozone Lidar Measurements}

The TOLNet lidar located at UAH (Rocket-city $\mathrm{O}_{3}$ Quality Evaluation in the Troposphere $\left(\mathrm{RO}_{3} \mathrm{QET}\right)$ ) is a Differential Absorption Lidar (DIAL) and is located at $34.725^{\circ} \mathrm{N}$ and $86.645^{\circ} \mathrm{W}$ and $\sim 206 \mathrm{~m}$ above sea level (asl). The UAH TOLNet site is located in Huntsville, Alabama which is the fourth largest city in the state and represents a typical mid-latitude city in the southeastern U.S. This site is moderately polluted with its air quality being influenced by several surrounding larger cities: Birmingham, Alabama, Memphis, Tennessee, Nashville, Tennessee, and Atlanta, Georgia. Huntsville, Alabama experiences a humid subtropical climate typical of the southeast US with high temperatures in June on average reaching values $>30^{\circ} \mathrm{C}$ and receiving $>4$ inches of rain for the month.

The DIAL technique used by the UAH TOLNet lidar derives $\mathrm{O}_{3}$ concentrations by analyzing the difference in backscattered signals at two separate but closely-spaced wavelengths, one strongly absorbed by $\mathrm{O}_{3}$ (on-line wavelength) and the other less strongly absorbed (off-line wavelength). The 
transmitter of the $\mathrm{RO}_{3} \mathrm{QET}$ lidar comprises two Raman-shifted lasers at 289 and $299 \mathrm{~nm}$. A 30-Hz, 266-nm Nd:YAG laser pumps a 1.8-m Raman cell with a mixture of deuterium and helium to generate the on-line laser at $289 \mathrm{~nm}$ with an output energy of $7 \mathrm{~mJ} /$ pulse. Another 266-nm Nd:YAG laser with the same frequency pumps another Raman cell with a mixture of hydrogen and argon to produce the off-line laser at $299 \mathrm{~nm}$ with an output energy of $5 \mathrm{~mJ} /$ pulse. The receiving system consists of three receivers at $2.5,10$, and $40 \mathrm{~cm}$, and four photomultipliers similar to that described by [15]. Due to the fact that a 300-nm short-pass filter is used as a solar-blind filter for all channels, the day-time maximum measurable altitude is only $\sim 5 \mathrm{~km}$. The night-time measurable altitude can reach heights up to $15 \mathrm{~km}$ due to less solar background.

The UAH TOLNet lidar observed vertical profiles of $\mathrm{O}_{3}$ mixing ratios at 150 (lower troposphere) to 750 (upper troposphere) meter resolution every $2 \mathrm{~min}$. The accuracy of the system has been discussed in previous studies and Lidar measurement precision is estimated to be $\pm 10 \%$ in the lower troposphere and $\pm 20 \%$ in the upper troposphere $[15,16]$. Data from the UAH TOLNet lidar system is publically available [14] and has been used to examine atmospheric chemistry relevant topics such as air pollution transport, nocturnal $\mathrm{O}_{3}$ enhancements, stratosphere-troposphere exchange, boundary layer pollution entrainment, wildfire impacts on $\mathrm{O}_{3}$, and lightning $\mathrm{NO}_{x}$ generated $\mathrm{O}_{3}$ (e.g., [17-19]). During this study we evaluated all UAH TOLNet observations for the month of June 2013 to identify anomalous $\mathrm{O}_{3}$ lamina (see Section 3.1). In order to directly compare TOLNet data to GEOS-Chem hourly $\mathrm{O}_{3}$ predictions, lidar data is hourly-averaged within the GEOS-Chem vertical grid in which each measurement was obtained.

\subsection{Ground-Based and Airborne in Situ Measurements}

GEOS-Chem predictions of $\mathrm{O}_{3}$ and major precursor species (CO, $\mathrm{NO}_{x}$, Isoprene (ISOP)) were evaluated using ground-based and airborne in situ data in addition to TOLNet observations. The ground-based $\mathrm{O}_{3}$ observations used during this study were obtained from the SEARCH Network [20] and EPA AQS from the AirData website [21] for the entire month of June 2013. Two SEARCH sites in Alabama were used in this study, one site representative of urban (North Birmingham, Alabama (BHM)) and rural (Centreville, Alabama (CTR)) regions. Surface-based $\mathrm{O}_{3}$ observations from the 15 EPA AQS stations with continuous measurements made in Alabama during the month of June 2013 were used for evaluation. To understand the ability of the model to simulate surface $\mathrm{O}_{3}$, hourly-averaged SEARCH and EPA AQS surface observations are compared to hourly-averaged GEOS-Chem predictions in the lowest model grid in which the measurement was obtained. Airborne measurements of $\mathrm{O}_{3}, \mathrm{CO}, \mathrm{NO}_{\mathrm{x}}$, and ISOP were also applied during this study from the NOAA WP-3D aircraft during the SENEX field campaign [22]. For model evaluation purposes, the airborne measurements from flights on 12 and 29 June 2013 were compared to simulated values in the horizontal and vertical model grid in which they were obtained (flight tracks displayed in Figure S1).

\subsection{GEOS-Chem Model}

During this work, the global/regional 3D CTM GEOS-Chem (v9-02) was applied to simulate emissions, atmospheric chemistry, and transport of $\mathrm{O}_{3}$ and its precursor gases. GEOS-Chem is driven by assimilated meteorological fields from the Goddard Earth Observing System version 5 (GEOS-5) of the National Aeronautics and Space Administration (NASA) Global Modeling Assimilation Office (GMAO) [23]. The model was run in a regional nested-grid mode with a horizontal resolution of $0.25^{\circ} \times 0.3125^{\circ}$ (latitude $\times$ longitude) and 47 vertical hybrid sigma-pressure levels over North America $\left(130^{\circ} \mathrm{W}-60^{\circ} \mathrm{W}, 9.75^{\circ} \mathrm{N}-60^{\circ} \mathrm{N}\right)$. GEOS-Chem includes $\mathrm{H}_{2} \mathrm{SO}_{4}-\mathrm{HNO}_{3}-\mathrm{NH}_{3}$ aerosol thermodynamics coupled to an $\mathrm{O}_{3}-\mathrm{NO}_{\mathrm{x}}$-hydrocarbon-aerosol chemical mechanism [23]. Transport of aerosol and gaseous species is calculated every $10 \mathrm{~min}$ in the model using the TPCORE parameterization which is based on the scheme described in [24]. To simulate boundary layer mixing of aerosol and trace gases the model applies a non-local scheme based on atmospheric stability [25]. The model treats wet deposition applying the methods described by [26] for water-soluble aerosols and by [27] for 
gases. Dry deposition in the model is based on the resistance-in-series scheme described in [28]. The GEOS-Chem model simulations during this study include the modifications to emissions, chemistry, and deposition processes described in [29] which improved the model performance compared to observational data obtained in the southeast US during the SEAC ${ }^{4} \mathrm{RS}$ campaign which took place during the summer of 2013. 3-h dynamic boundary conditions for nested model runs are prescribed from global GEOS-Chem simulations with a $2^{\circ} \times 2.5^{\circ}$ resolution.

Anthropogenic emissions in the US applied during this study were taken from the 2008 National Emissions Inventories (NEI2008) developed by the US EPA. The NEI2008 emission inventory is provided at a $12 \mathrm{~km} \times 12 \mathrm{~km}$ resolution and was re-gridded to match the horizontal resolution $\left(0.25^{\circ} \times 0.3125^{\circ}\right)$ of GEOS-Chem. Scaling factors were applied to all emitted chemical species to represent anthropogenic emissions in the year 2013 using the ratio of national annual totals [30]. Recent studies have shown that $\mathrm{NO}_{\mathrm{x}}$ emissions from sources other than power plants (i.e., mobile sources) in this inventory, which contribute significantly to total $\mathrm{NO}_{\mathrm{x}}$ emissions, are overestimated and in this study the NEI emission rates are reduced by $50 \%$ similar to many recent studies (e.g., [29,31-34]).

Many natural sources, such as wildfires/biomass burning, lightning $\mathrm{NO}_{\mathrm{x}}$ emissions, and stratospheric intrusions, have large impact on tropospheric $\mathrm{O}_{3}$ in North America. During this study, wildfire and biomass burning emissions are simulated using data from the Quick Fire Emissions Dataset (QFED version 2) at a $0.1^{\circ} \times 0.1^{\circ}$ resolution [35]. Daily QFEDv2 emission data are re-gridded to match the $0.25^{\circ} \times 0.3125^{\circ}$ horizontal resolution of GEOS-Chem. Biomass burning emissions of individual species are driven by Moderate Resolution Imaging Spectroradiometer (MODIS) fire location detection and fire radiative power at a $1 \mathrm{~km} \times 1 \mathrm{~km}$ spatial resolution. An additional natural source which largely contributes to summer-time tropospheric $\mathrm{O}_{3}$ in North America is the emission of $\mathrm{NO}_{\mathrm{x}}$ from lightning. GEOS-Chem calculates an online lightning source of $\mathrm{NO}_{\mathrm{x}}$ as a function of GEOS-5 deep convective cloud top heights which is scaled to match Optical Transient Detector (OTD) and the Lightning Imaging Sensor (LIS) climatological observations [36]. Yields of $\mathrm{NO}_{\mathrm{x}}$ per flash are typically set to 260 and 500 moles in the tropics and extra-tropics, respectively [36,37]. However, during this study $\mathrm{NO}_{x}$ per flash yields in the southeast US are treated as tropical instead of extra-tropical in order to reduce biases in upper tropospheric $\mathrm{O}_{3}$ and $\mathrm{NO}_{x}$ mixing ratios compared to measurement data taken during SEAC ${ }^{4}$ RS in the summer of 2013 [29].

Stratospheric $\mathrm{O}_{3}$ is calculated in the baseline model applying the Linoz linearized parameterization [38]. Stratospheric $\mathrm{O}_{3}$ calculations are made above the dynamic tropopause and transported to the troposphere using $3 \mathrm{D}$ winds from the $0.25^{\circ} \times 0.3125^{\circ}$ GEOS-5 model. This parameterization results in a stratosphere-to-troposphere $\mathrm{O}_{3}$ flux of $\sim 500 \mathrm{Tg} \cdot \mathrm{year}^{-1}$ which is consistent with observations (e.g., [38,39]) and other Eulerian models applying full stratospheric chemistry mechanisms (e.g., [7]). In a recent study it was shown the GEOS-Chem, run at a coarser $0.5^{\circ} \times 0.67^{\circ}$ spatial resolution, was able to capture the timing of stratospheric intrusions impacting surface $\mathrm{O}_{3}$ in the western US, but displayed a low bias compared to observations when strong stratospheric intrusions occurred [9]. During this study we simulate stratospheric $\mathrm{O}_{3}$ using a finer spatial resolution of $0.25^{\circ} \times 0.3125^{\circ}$ which was shown in the GEOS- 5 model to calculate higher magnitudes and similar spatio-temporal distributions of the influence of stratospheric air at the surface compared to simulations applying a $0.5^{\circ} \times 0.67^{\circ}$ resolution [40]. Furthermore, in the work by [9] it was demonstrated that stratospheric $\mathrm{O}_{3}$ can be defined in two ways: (1) natural $\mathrm{O}_{3}$ that is formed in the stratosphere; and (2) all $\mathrm{O}_{3}$ that is transported above the tropopause (formed in both the stratosphere and troposphere). The different definitions resulted in greater than a factor of 2 differences between calculated stratospheric $\mathrm{O}_{3}$ impacts at the surface. Baseline GEOS-Chem simulations during this study consider stratospheric $\mathrm{O}_{3}$ that is only naturally formed above the tropopause. However, additional analysis is conducted in order to avoid any potential biases in the stratospheric $\mathrm{O}_{3}$ parameterization in GEOS-Chem by applying GMAO GEOS-5 potential vorticity (PV) in order to estimate stratospheric $\mathrm{O}_{3}$ in the troposphere (see the explanation in Section 2.4). 


\subsection{Model-Predicted Sources of Ozone}

In order to quantify the impact of North American anthropogenic emissions, wildfires/biomass burning, lightning $\mathrm{NO}_{\mathrm{x}}$, and long-range/stratospheric sources to total $\mathrm{O}_{3}$ measured over the UAH TOLNet lidar location during June 2013 we performed additional GEOS-Chem sensitivity simulations. This was done by running "brute force" source apportionment simulations in which: (1) North American anthropogenic emissions; (2) wildfires/biomass burning; (3) lightning $\mathrm{NO}_{\mathrm{x}}$; and (4) all North American emissions besides biogenic sources (only tropospheric $\mathrm{O}_{3}$ and precursor species provided from boundary conditions and stratospheric transport contributed to predicted $\mathrm{O}_{3}$, hereinafter referred to as long-range transport $\mathrm{O}_{3}$ ) were set to zero. The difference between $\mathrm{O}_{3}$ predicted during the baseline simulation and sensitivity source apportionment model runs were quantified and attributed to the individual source which was set to zero. During all sensitivity simulations the model was spun up for 1 month prior to June 2013. The "brute force" method applied during this study is effective in determining emission sources or processes impacting $\mathrm{O}_{3}$ during case studies and has been applied in numerous recent studies (e.g., $[9,13])$, but non-linear chemistry effects could potentially impact the exact model-predicted contributions from each source (e.g., [41,42]). While these non-linear chemistry signals typically occur in highly polluted regions, in order to determine if non-linear effects were impacting the source attribution calculations during this study, we compare summations of all individual sources to total model-predicted $\mathrm{O}_{3}$ mixing ratios. On average, non-linear chemistry effects were minimal over the UAH TOLNet site with sensitivity simulation summations being on average within $\pm 10 \%$ of total $\mathrm{O}_{3}$ predicted by the baseline model (see Figure S2). However, due to some minor non-linear effects being calculated during sensitivity studies, exact mixing ratio magnitudes of source apportioned $\mathrm{O}_{3}$ and the percent contribution to total $\mathrm{O}_{3}$ (which are presented in order to demonstrate relative importance of each source type) should be understood to have some small range of uncertainty.

During this study we apply two methods to estimate the amount of tropospheric $\mathrm{O}_{3}$ measured by TOLNet that is associated with just stratospheric transport. The first method is based upon the numerous recent studies that have used $\mathrm{O}_{3}: \mathrm{PV}$ ratios as a tracer for stratospheric air and $\mathrm{O}_{3}$ (e.g., $[18,43-46])$. To calculate stratospheric $\mathrm{O}_{3}$ mixing ratios we multiple GEOS-5 potential vorticity unit (PVU, $1 \mathrm{PVU}=10^{6} \mathrm{~K} \mathrm{~m}^{2} \mathrm{~kg}^{-1} \mathrm{~s}^{-1}$ ) values by an $\mathrm{O}_{3}: \mathrm{PV}$ ratio of $41 \mathrm{nmol} \mathrm{mol}^{-1} / \mathrm{PVU}$. This value was chosen as it was derived from a study using TOLNet observations and model simulations to calculate $\mathrm{O}_{3}: \mathrm{PV}$ ratios associated with stratospheric transport at the location of the UAH TOLNet lidar site [18]. This value falls within the range of $\mathrm{O}_{3}: \mathrm{PV}$ ratios of $30-45 \mathrm{nmol} \mathrm{mol}^{-1} / \mathrm{PVU}$ reported for stratospheric $\mathrm{O}_{3}$ in past studies (e.g., [43-46]). A second method was applied in order to estimate the amount of $\mathrm{O}_{3}$ measured by TOLNet which is associated with "pure" stratospheric intrusions based on methods described in [45]. In order to remove PV and $\mathrm{O}_{3}$ associated with photochemically generated tropospheric values we compute monthly-averaged $\mathrm{PV}$ and $\mathrm{O}_{3}: \mathrm{PV}$ ratios during June 2013. During this month, averaged tropospheric PV values were calculated to be $0.45 \mathrm{PVU}$ and $\mathrm{O}_{3}: \mathrm{PV}$ ratios around $300 \mathrm{mb}$ were $89.3 \mathrm{nmol} \mathrm{mol}^{-1} / \mathrm{PVU}$. To separate "pure" stratospheric $\mathrm{O}_{3}$ from tropospheric air, we eliminate model predictions with PVU values $<0.45$ and $\mathrm{O}_{3}: \mathrm{PV}$ ratios $>89.3 \mathrm{nmol} \mathrm{mol}^{-1} / \mathrm{PVU}$. To calculate the "pure" stratospheric $\mathrm{O}_{3}$ mixing ratios we then multiple the remaining GEOS-5 PVU values by the $\mathrm{O}_{3}: \mathrm{PV}$ ratio of $41 \mathrm{nmol} \mathrm{mol}^{-1} / \mathrm{PVU}$. During some days anomalously large PVU values (>1.0) were simulated by GEOS-5 in the planetary boundary layer (PBL). It has been demonstrated that boundary layer processes (e.g., diabatic heating/cooling, boundary layer friction) can produce PV and is not associated with stratospheric air (e.g., [47,48]). In order to remove these occurrences we replace these anomalous PVU values in the PBL with daily PBL-averaged PVU from GEOS-5. Both the methods described above make assumptions (e.g., $\mathrm{O}_{3}: \mathrm{PV}$ ratio) which could lead to uncertainties in model-predicted stratospheric $\mathrm{O}_{3}$. However, these methods are specifically designed to identify/estimate stratospheric sources impacting anomalous tropospheric $\mathrm{O}_{3}$ lamina at different vertical levels in the southeast US and in no way attempts to identify the contribution of stratospheric $\mathrm{O}_{3}$ to policy-relevant issues (such as air quality exceedance events). For clarification, when discussing "long-range transport" or "long-range/stratospheric" sources we are referring to $\mathrm{O}_{3}$ 
magnitudes calculated during sensitivity simulation \#4 where all North American emissions are set to zero (long-range and stratospheric transport contributing to predicted $\mathrm{O}_{3}$ ). The stratospheric $\mathrm{O}_{3}$ magnitudes from this sensitivity simulation are from the baseline model applying the Linoz linearized parameterization. When identifying/estimating stratospheric $\mathrm{O}_{3}$ mixing ratios only, we are referring to the additional methods described above based on GEOS-5 PVU values.

\section{Results and Discussion}

\subsection{TOLNet Observations of Enhanced $\mathrm{O}_{3}$ during June 2013}

TOLNet observations were analyzed for the entire month of June 2013 and two $\mathrm{O}_{3}$ enhancement cases on 12 and 29 June 2013 were chosen for model evaluation and source apportionment quantification. Figure 1 shows curtain plots of TOLNet observed $\mathrm{O}_{3}$ mixing ratios on 12 June 2013 between 00 and 22 UTC and on 28 June 2013 at 18 UTC to 29 June 2013 at 07 UTC (Central Daylight Time $(C D T)=U T C-5 \mathrm{~h}$ ). The first case study from 12 June 2013 captured a nocturnal $\mathrm{O}_{3}$ enhancement which occurred near the surface. This study focuses on the time in which the nocturnal $\mathrm{O}_{3}$ enhancement increased from $\sim 65 \mathrm{nmol} \mathrm{mol}^{-1}$ to $\sim 90 \mathrm{nmol} \mathrm{mol}^{-1}$ from 02 to 08 UTC (11 June-09pm to 12 June-03am CDT) (Figure 1a). The second case study is from 29 June 2013 when between 01 and 05 UTC (28 June- $-08 \mathrm{pm}$ to 29 June-12am CDT) a large $\mathrm{O}_{3}$ enhancement layer between $\sim 3$ and $6 \mathrm{~km}$ above ground level was observed. Ozone mixing ratios during this time reached values of 80 to $>100 \mathrm{nmol} \mathrm{mol}^{-1}$ between 03 and 04 UTC (10-11pm CDT). These two case studies were chosen due to the large $\mathrm{O}_{3}$ mixing ratios observed and to evaluate enhancement layers near the surface and in the free troposphere. These events provide a unique opportunity to study sources and transport processes which impact $\mathrm{O}_{3}$ lamina during the summer at different vertical locations in the troposphere of the southeast US.

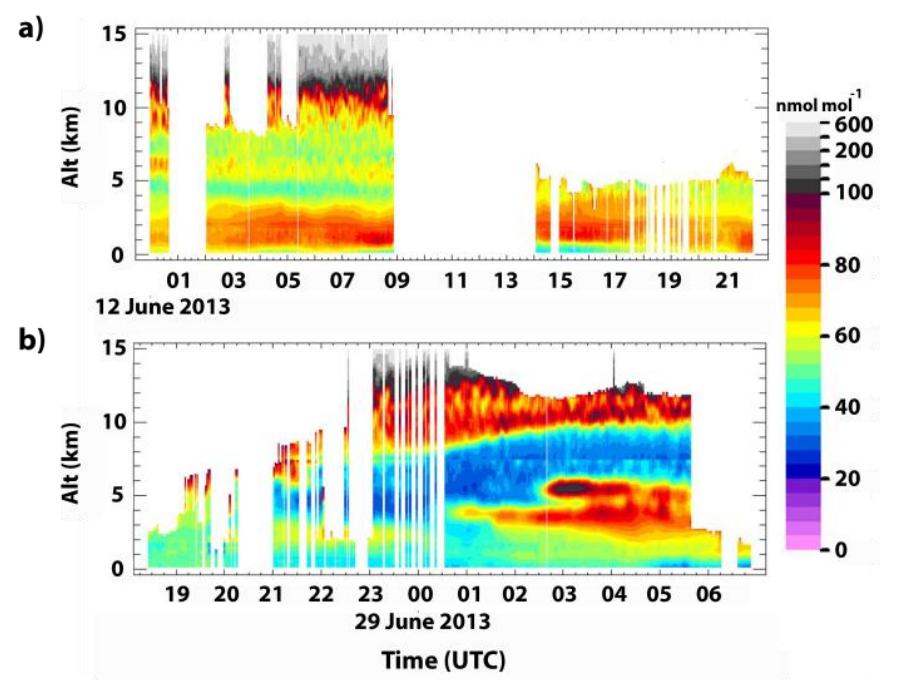

Figure 1. UAH TOLNet observations of $\mathrm{O}_{3}\left(\mathrm{nmol} \mathrm{mol}^{-1}\right)$ on (a) 12 June 2013 and (b) 28-29 June 2013.

Figure 2 shows the comparison of GEOS-Chem-predicted and TOLNet observations of vertically resolved $\mathrm{O}_{3}$ averaged between 02 and 08 UTC on 12 June 2013 and 01 to 05 UTC on 29 June 2013. The time-period on 12 June 2013 was selected as TOLNet observations indicated the largest enhancement occurred during these times (see Figure 1a) and the model displayed the relative ability to capture the observed $\mathrm{O}_{3}$ vertical profile (Figure 2a). While the model displays a noticeable negative bias below $\sim 3 \mathrm{~km}$, the model does capture the enhancement occurring at this time and the general pattern of vertically-resolved $\mathrm{O}_{3}$ observed by TOLNet (correlation coefficient $(\mathrm{R})=0.35$ ). Compared to monthly-average model-predicted vertical $\mathrm{O}_{3}$ profiles, the model predicted a nocturnal $\mathrm{O}_{3}$ enhancement of $\sim 10-20 \mathrm{nmol} \mathrm{mol}^{-1}$ below $3 \mathrm{~km}$ on 12 June 2013 between 02 and 08 UTC. When 
comparing the temporally-averaged vertical profile predicted by GEOS-Chem to TOLNet observations the overall normalized mean bias (NMB) was $\sim-18 \%$ between 02 and 08 UTC, primarily driven by the low bias below $3 \mathrm{~km}$.
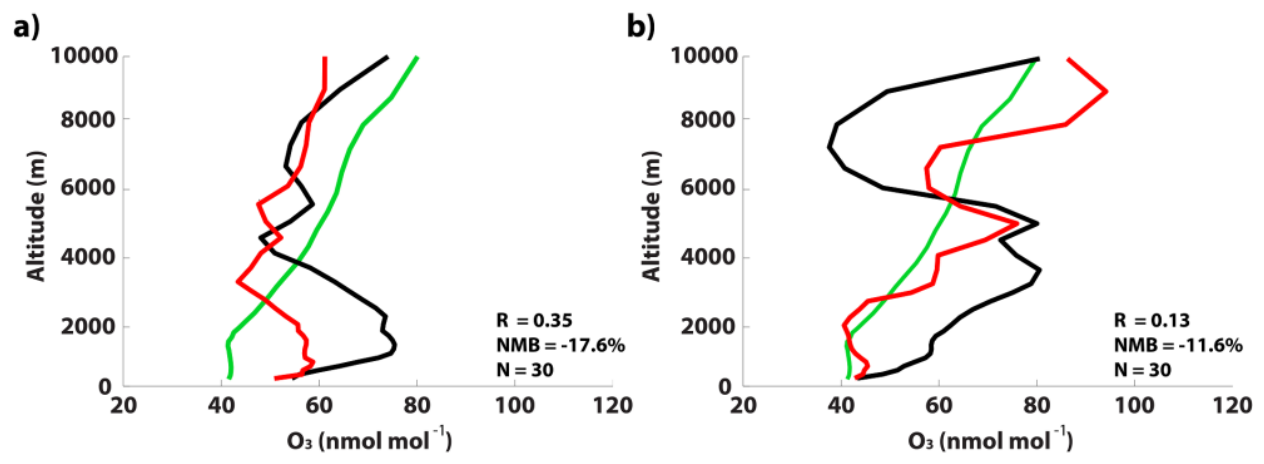

Figure 2. GEOS-Chem-predicted (red line) and TOLNet-observed (black line) average $\mathrm{O}_{3}$ mixing ratios (nmol mol ${ }^{-1}$ ) on (a) 12 June 2013 between 02 UTC and 08 UTC and (b) 29 June 2013 between 01 and 05 UTC. Monthly-averaged vertical profiles of $\mathrm{O}_{3}$ predicted by GEOS-Chem at the UAH TOLNet location during June 2013 are also displayed for reference (green line).

Figure $2 \mathrm{~b}$ shows temporally-averaged TOLNet and GEOS-Chem-predicted vertical $\mathrm{O}_{3}$ profiles from 01 to 05 UTC on 29 June 2013. Similar to the case study on 12 June 2013, this time was selected in order to evaluate the largest $\mathrm{O}_{3}$ enhancement occurring on this day and the model displaying the relative ability to reproduce the enhancement layer. From Figure $2 b$ it is clear that GEOS-Chem once again displays a negative bias ( $\mathrm{NMB}=-11.6 \%$ ), however, is able to reproduce the large enhancement layer occurring between 3 and $6 \mathrm{~km}$. Compared to monthly-average model-predicted $\mathrm{O}_{3}$ values, the model predicted an $\mathrm{O}_{3}$ enhancement between 3 and $6 \mathrm{~km}$ of $\sim 10-20 \mathrm{nmol} \mathrm{mol}^{-1}$ on 29 June 2013 between 01 and 05 UTC. The model does appear to display a large overestimation of $\mathrm{O}_{3}$ above $6 \mathrm{~km}$ leading to lower correlation values $(\mathrm{R}=0.13)$ between the model and TOLNet observations, but overall is able to reproduce the vertical $\mathrm{O}_{3}$ profile occurring at these times.

Due to the fact that the model reproduces the occurrence of the nocturnal $\mathrm{O}_{3}$ enhancement layer on 12 June and the elevated $\mathrm{O}_{3}$ enhancement lamina on 29 June (and the general pattern of vertical profiles of $\mathrm{O}_{3}$ measured by TOLNet) provides confidence in using the model to evaluate sources impacting TOLNet observations during these times. In order to further determine the ability of the model to simulate $\mathrm{O}_{3}$, and precursor species, during the entire month of June 2013 in the southeast US, GEOS-Chem predictions were evaluated using ground-based and airborne in situ data (see Section 3.2).

\subsection{GEOS-Chem Evaluation}

In order to evaluate the ability of GEOS-Chem to reproduce the spatio-temporal variability of $\mathrm{O}_{3}$ occurring in the southeast US, we compare model predictions to surface data from the SEARCH Network and EPA AQS. Figure 3 shows the comparison of hourly-averaged GEOS-Chem-predicted $\mathrm{O}_{3}$ and observations from the BHM and CTR SEARCH Networks in Alabama and all EPA AQS stations in Alabama with data available for all of June 2013 (15 total stations). When comparing the model to surface measurement data at all hours of the day (Figure 3a-c) statistical analysis shows that the model demonstrates relatively good correlations $(R=0.39$ to 0.61$)$ and a consistent high bias $(\mathrm{NMB}=25.5 \%$ to $37.1 \%)$. During the model evaluation, time-series analysis clearly demonstrated that this high bias was primarily caused by the model over-predicting the very low night-time $\mathrm{O}_{3}$ values measured at the surface (often well below $10 \mathrm{nmol} \mathrm{mol}^{-1}$ ). Figure $3 \mathrm{~d}$ shows that when removing night-time measurement data (only comparing the model to EPA AQS measurements taken between 17 and 22 UTC (12 to $05 \mathrm{pm} \mathrm{CDT))} \mathrm{the} \mathrm{model} \mathrm{NMB} \mathrm{was} \mathrm{reduced} \mathrm{to}<1 \%$. This result indicates that some transport, chemical, or depositional process occurring during the night is not well captured in 
GEOS-Chem at the surface layer. However, when the model is compared to the TOLNet observations of the nocturnal near surface $\mathrm{O}_{3}$ enhancement evaluated during this study (Figure 2a) it is shown that the model captures the surface-level $\mathrm{O}_{3}$ mixing ratios and the magnitude of $\mathrm{O}_{3}$ above the large enhancement $(>3 \mathrm{~km})$. Figure 4 shows the comparison of airborne measurements of $\mathrm{O}_{3}$ taken on NOAA P3 flights during SENEX and GEOS-Chem predictions on 12 and 29 June 2013 (days in which TOLNet observations of $\mathrm{O}_{3}$ enhancement occurred, flight tracks displayed in Figure S1). During both flights the model demonstrates a relatively strong ability to capture the magnitudes ( $\mathrm{NMB}=-10 \%$ to $2.1 \%$ ) and spatio-temporal variability of measured $\mathrm{O}_{3}(\mathrm{R}=0.37$ to 0.78$)$. The comparison to airborne data suggests that the model may better reproduce $\mathrm{O}_{3}$ aloft compared to surface level mixing ratios. This is an important finding due to the fact the model is applied in this study to evaluate $\mathrm{O}_{3}$ lamina measured by TOLNet above the surface. Overall, the fact that GEOS-Chem-predicted vertically distributed $\mathrm{O}_{3}$ in the southeast US compared relatively well to in situ data obtained during SENEX flights provides confidence in applying GEOS-Chem to evaluate source attribution of TOLNet $\mathrm{O}_{3}$ observations.

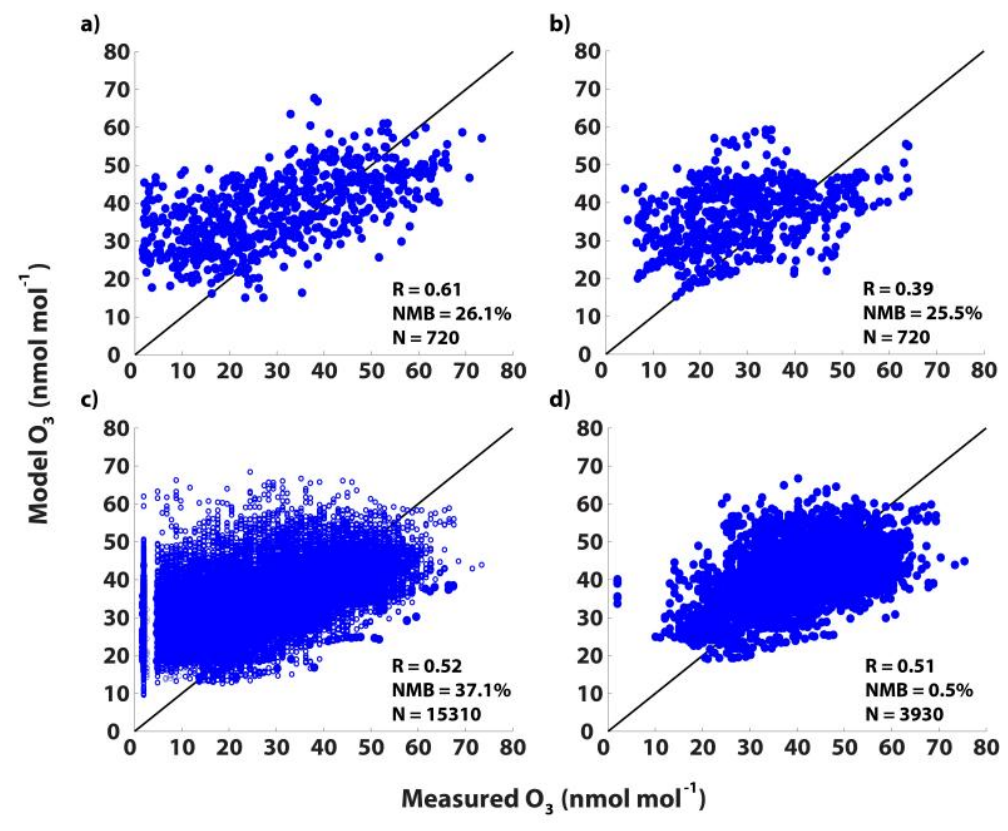

Figure 3. Comparison of surface-level hourly-averaged GEOS-Chem-predicted $\mathrm{O}_{3}$ and observations $\left(\mathrm{nmol} \mathrm{mol}^{-1}\right)$ from the SEARCH Networks located in (a) Birmingham, Alabama (BHM); (b) Centreville, Alabama (CTR); (c) all EPA AQS stations in Alabama (1-24 UTC); and (d) all EPA AQS stations in Alabama (17-22 UTC).

To determine the capability of the model to reproduce the magnitudes and statio-temporal variability of $\mathrm{O}_{3}$ precursor species during the days of the two case studies, we compare predicted values of $\mathrm{CO}, \mathrm{NO}_{\mathrm{x}}$, and ISOP to P3 data. SENEX measurements was chosen as the primary source of data for this portion of the model evaluation due to the fact it provides measurement data throughout the troposphere and contains information of all precursor species. Table 1 illustrates this model evaluation during the two P3 flights on 12 and 29 June 2013. From this table it can be seen that the model predicts $\mathrm{CO}$ mixing ratios that were highly correlated $(\mathrm{R}>0.75)$ with small low biases $(\mathrm{NMB}=-21 \%--23 \%)$ compared to $\mathrm{P} 3$ measurement data over the southeast US. When evaluating $\mathrm{NO}_{2}$ predictions by GEOS-Chem, the model displays moderate correlation $(\mathrm{R}=0.3-0.6)$ and small low biases $(\mathrm{NMB}=$ $-3 \%--19 \%$ ). Lower correlation ( $\mathrm{R}=0.2-0.4)$ and positive biases ( $\mathrm{NMB}=24 \%-56 \%$ ) were determined when comparing GEOS-Chem NO predictions to the P3 data. Finally, model-predicted ISOP values were generally higher compared to measurements ( $\mathrm{NMB}=60 \%-85 \%)$ with high correlation $(\mathrm{R}=\sim 0.6)$ during both P3 flights over the southeast US. Overall, when compared to airborne measurement data over the southeast US, small to moderate biases in model-predicted $\mathrm{O}_{3}$ precursor species were 
calculated. These model biases are similar in magnitude to other modeling studies in this region (e.g., $[29,34])$ providing further confidence in applying GEOS-Chem to evaluate source attribution of TOLNet $\mathrm{O}_{3}$ observations.

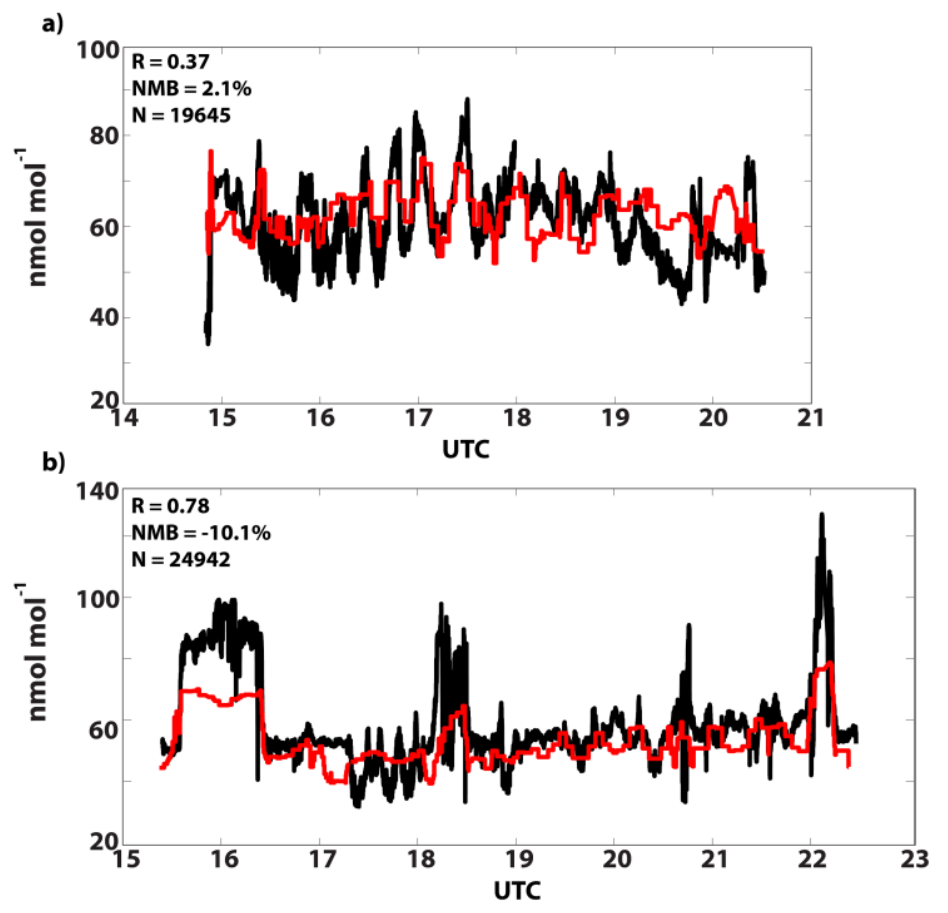

Figure 4. GEOS-Chem-predicted $\mathrm{O}_{3}$ (red line) compared to instantaneous measurements from NOAA P3 flights (black line) on (a) 12 June 2013 and (b) 29 June 2013.

Table 1. GEOS-Chem evaluation of $\mathrm{O}_{3}$ precursor species (CO, $\mathrm{NO}_{\mathrm{x}}$, ISOP) using measurement data from NOAA P3 flights during SENEX on 12 and 29 June 2013.

\begin{tabular}{|c|c|c|c|c|}
\hline \multicolumn{5}{|c|}{ SENEX Flight-12 June } \\
\hline & $\mathrm{CO}$ & $\mathrm{NO}_{2}$ & NO & ISOP \\
\hline Measure (Mean) * & 153.5 & 0.40 & 0.06 & 1.00 \\
\hline Model (Mean) * & 120.8 & 0.39 & 0.10 & 1.61 \\
\hline NMB (\%) & -21.33 & -3.11 & 55.93 & 60.50 \\
\hline Correlation (R) & 0.89 & 0.67 & 0.42 & 0.63 \\
\hline \multicolumn{5}{|c|}{ SENEX Flight-29 June } \\
\hline & $\mathrm{CO}$ & $\mathrm{NO}_{2}$ & NO & ISOP \\
\hline Measure (Mean) * & 123.14 & 0.24 & 0.05 & 0.65 \\
\hline Model (Mean)* & 94.02 & 0.20 & 0.06 & 1.20 \\
\hline NMB (\%) & -23.65 & -18.67 & 23.94 & 84.82 \\
\hline Correlation (R) & 0.76 & 0.31 & 0.19 & 0.59 \\
\hline
\end{tabular}

* Measured and model mixing ratios are in $\mathrm{mmol} \mathrm{mol}^{-1}$.

\subsection{Sources of $\mathrm{O}_{3}$ Measured by TOLNet}

\subsubsection{Monthly-Averaged Source Attribution during June 2013}

In order to determine the emission sources and transport pathways that were contributing to total $\mathrm{O}_{3}$ over the UAH TOLNet site during June 2013, "brute force" sensitivity simulations were conducted to quantify $\mathrm{O}_{3}$ production due to North American anthropogenic emissions, wildfires, lightning $\mathrm{NO}_{\mathrm{x}}$, and long-range/stratospheric transport. To evaluate the contribution from individual 
emission sources and transport processes to total $\mathrm{O}_{3}$ during summer months, we compute source specific $\mathrm{O}_{3}$ magnitudes and the percent contribution to total $\mathrm{O}_{3}$ for the entire month of June 2013. Monthly-averaged $\mathrm{O}_{3}$ source attribution is shown in Figure $5 \mathrm{a}, \mathrm{b}$ and from this figure it can be seen that near the surface $(<2 \mathrm{~km})$ anthropogenic emissions and long-range transport (long-range tropospheric + stratospheric) $\mathrm{O}_{3}$ make up the majority of model predicted $\mathrm{O}_{3}$. The source attribution of total $\mathrm{O}_{3}$ aloft $(>3 \mathrm{~km})$ is predominantly contributed from long-range/stratospheric transport, lightning $\mathrm{NO}_{\mathrm{x}}$, and anthropogenic emissions.
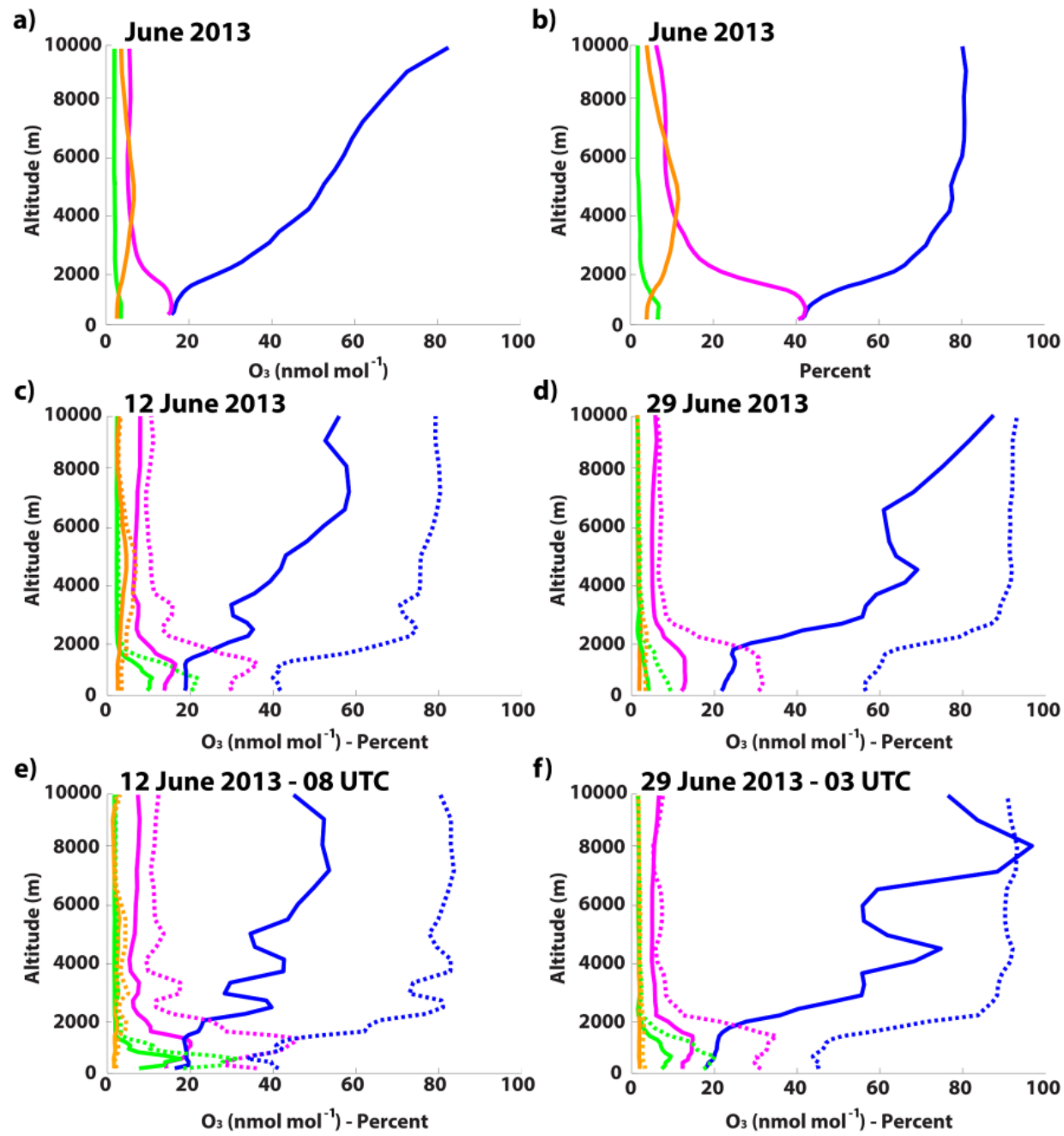

Figure 5. GEOS-Chem-predicted source contribution of $\mathrm{O}_{3}\left(\mathrm{nmol} \mathrm{mol}^{-1}\right)$ from North American anthropogenic emissions (magenta line), wildfires (green line), lightning $\mathrm{NO}_{\mathrm{x}}$ (orange line), and long-range/stratospheric (blue line) at the UAH TOLNet station. Monthly averaged (a) concentrations and (b) percent contribution to total $\mathrm{O}_{3}$ are shown for reference to daily/hourly values; Daily-averaged concentrations (solid lines) and percent contributions (dashed lines) are displayed for (c) 12 June 2013 and (d) 29 June 2013 along with hourly-averaged concentration and percent contributions at (e) 08 UTC on 12 June 2013 and (f) 03 UTC on 29 June 2013.

Table 2 shows the quantified model-predicted contribution from individual sources at the UAH TOLNet site for the entire month of June 2013 and the two case studies evaluated during this study (illustrated in Figure 5). The source-specific $\mathrm{O}_{3}$ magnitude and percent contribution are shown for monthly-averaged model predictions, daily-averaged values for 12 and 29 June 2013, and hourly-averaged values for 08 UTC (03am CDT) on 12 June 2013 (between 0-1 km and 0-3 km) and 03 UTC (10pm CDT) on 29 June 2013 (between 3 and $6 \mathrm{~km}$ ). Monthly-averaged source contribution of 
total $\mathrm{O}_{3}$ near the surface is predominantly from anthropogenic emissions $(\sim 36 \%$ and $44 \%$ below $3 \mathrm{~km}$ and $1 \mathrm{~km}$, respectively) and long-range/stratospheric transport ( $56 \%$ and $47 \%$ below $3 \mathrm{~km}$ and $1 \mathrm{~km}$, respectively). From Table 2 it can also be seen that total $\mathrm{O}_{3}$ between $3-6 \mathrm{~km}$ for the month of June 2013 is primarily from long-range/stratospheric transport ( $78 \%)$, anthropogenic emissions $(\sim 12 \%)$, and lightning $\mathrm{NO}_{\mathrm{x}}(\sim 9 \%)$. In order to estimate the amount of long-range transport $\mathrm{O}_{3}$ that is from only stratospheric transport we plot the vertical profiles of total long-range transport $\mathrm{O}_{3}$ (long-range tropospheric + stratospheric) and just stratospheric sources (based on GEOS-5 PVU) separately (see Figure 6). This figure shows the amount of total long-range transport $\mathrm{O}_{3}$ and just stratospheric $\mathrm{O}_{3}$ over the UAH TOLNet site for the entire month of June 2013, daily-averaged values for 12 and 29 June 2013, and hourly-averaged values for 08 UTC on 12 June 2013 and 03 UTC on 29 June 2013. From this figure it is shown that above $\sim 2 \mathrm{~km}$ during the month of June $2013, \sim 30 \%-80 \%$ of long-range transport $\mathrm{O}_{3}$ was from stratospheric transport (this estimate assumes that stratospheric $\mathrm{O}_{3}$ calculated from GEOS-5 PVU values is representative of stratospheric impact on total long-range transport $\mathrm{O}_{3}$ from GEOS-Chem).

Table 2. GEOS-Chem-predicted source-specific $\mathrm{O}_{3}$ magnitude ${ }^{\dagger}$ (percent contribution to total $\mathrm{O}_{3}$ ) for monthly-averaged model predictions, daily-averaged values for 12 and 29 June 2013, and hourly-averaged values for 08 UTC on 12 June 2013 (between 0-1 km and 0-3 km) and 03 UTC on 29 June 2013 (between 3 and $6 \mathrm{~km}$ ).

\begin{tabular}{cccc}
\hline Source (0-3 km) & June 2013 & 12 June 2013 & 12 June 2013 08 UTC \\
\hline Anthro & $14.3(35.6)$ & $12.8(30.1)$ & $14.5(33.9)$ \\
Wildfires & $1.5(3.8)$ & $5.5(13.0)$ & $5.6(13.1)$ \\
Lightning & $1.8(4.6)$ & $1.0(2.3)$ & $0.7(1.6)$ \\
LR + Strat * & $22.4(55.9)$ & $23.3(54.6)$ & $22.1(51.5)$ \\
\hline Source (0-1 km) & June 2013 & 12 June 2013 & 12 June 2013 08 UTC \\
\hline Anthro & $16.8(43.8)$ & $14.5(33.1)$ & $16.8(35.7)$ \\
Wildfires & $2.2(5.9)$ & $9.1(20.8)$ & $10.9(23.1)$ \\
Lightning & $1.1(2.9)$ & $0.8(1.8)$ & $0.5(1.0)$ \\
LR + Strat * & $18.1(47.4)$ & $19.4(44.4)$ & $18.9(40.2)$ \\
\hline Source (3-6 km) & June 2013 & 29 June 2013 & 29 June 2013 03 UTC \\
\hline Anthro & $6.4(11.6)$ & $4.4(6.5)$ & $4.4(6.4)$ \\
Wildfires & $0.4(0.7)$ & $0.8(1.2)$ & $0.7(1.0)$ \\
Lightning & $5.1(9.2)$ & $0.8(1.2)$ & $0.7(1.0)$ \\
LR + Strat * & $43.3(78.5)$ & $60.9(91.1)$ & $63.5(91.6)$ \\
\hline
\end{tabular}

+ Mixing ratios are in $\mathrm{nmol} \mathrm{mol}^{-1}$; ${ }^{*} \mathrm{LR}+$ Strat represents long-range/stratospheric $\mathrm{O}_{3}$ calculated during sensitivity simulations with all North American emissions set to zero. This represents long-range tropospheric transport and stratospheric $\mathrm{O}_{3}$ from baseline model simulations applying the Linoz linearized parameterization.

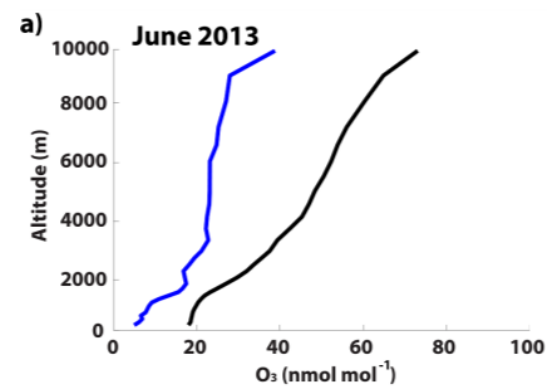

Figure 6. Cont. 

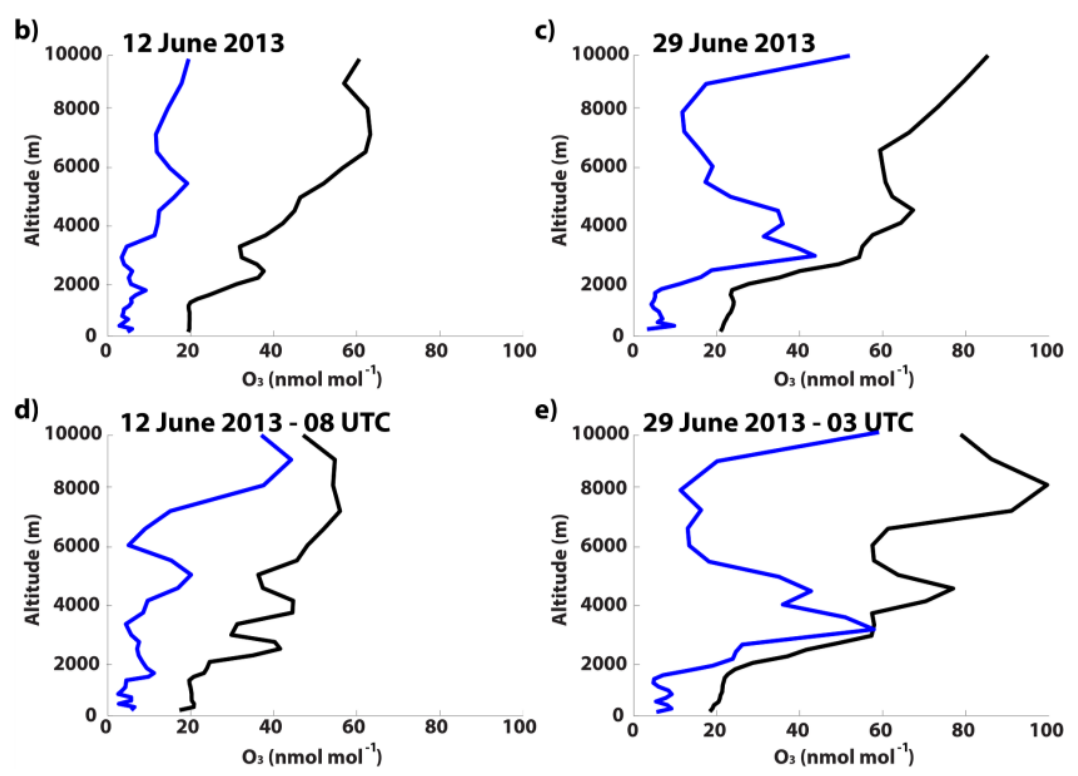

Figure 6. GEOS-Chem-predicted source contribution of $\mathrm{O}_{3}\left(\mathrm{nmol} \mathrm{mol}^{-1}\right)$ from long-range/stratospheric transport (black line) and just stratospheric transport based on GEOS-5 PVU (blue line) at the UAH TOLNet station. This figure displays (a) monthly averaged concentrations, daily-averaged concentrations for (b) 12 June 2013 and (c) 29 June 2013, and hourly-averaged concentrations at (d) 08 UTC on 12 June 2013 and (e) 03 UTC on 29 June 2013.

\subsubsection{June 2013}

TOLNet observations on 12 June 2013 captured a nocturnal $\mathrm{O}_{3}$ enhancement layer near the surface between 02 and 08 UTC. To determine the emission sources and transport processes contributing to the enhancement measured by TOLNet on 12 June 2013, "brute force" sensitivity simulations were conducted. Sensitivity studies were conducted to determine the source attribution of $\mathrm{O}_{3}$ for the entire day and during the hour in which largest enhancements were measured (08 UTC). The results of these sensitivity studies are presented in Figure $5 c, e$, respectively. From this figure it can be seen that the model predicted anthropogenic emission sources and long-range transport $\mathrm{O}_{3}$ to be the main sources contributing to $\mathrm{O}_{3}$ near the surface on 12 June 2013 with values ranging between 15 and $20 \mathrm{nmol} \mathrm{mol}^{-1}$. When near-surface $\mathrm{O}_{3}$ enhancements were measured to be at a maximum at $08 \mathrm{UTC}$, the model predicts a large impact from wildfire emissions with values reaching $>15 \mathrm{nmol} \mathrm{mol}^{-1}$ (below $1.5 \mathrm{~km}$ ) and anthropogenic emissions contribution had a daily maximum during these night-time hours. The model predicts a maximum daily contribution from anthropogenic emissions during the night-time hours (between 02 and 08 UTC) instead of the afternoon hours on 12 June 2013. GEOS-5 meteorological data indicates that a weak low level jet (LLJ) may have been occurring as the westerly wind component (U wind) below $2 \mathrm{~km}$ increased from $<5 \mathrm{~m} \cdot \mathrm{s}^{-1}$ at $00 \mathrm{UTC}\left(07 \mathrm{pm} \mathrm{CDT)} \mathrm{to}>10 \mathrm{~m} \cdot \mathrm{s}^{-1}\right.$ at 09 UTC (04am CDT). LLJs occur frequently in the southeast US and can transport $\mathrm{O}_{3}$ and precursor species from urban regions to rural areas in the late afternoon and night-time hours resulting in nocturnal $\mathrm{O}_{3}$ enhancements (e.g., [17]). Long-range/stratospheric sources contributed $\mathrm{O}_{3}$ mixing ratios near the surface which were similar to monthly-averaged values $\left(\sim 20 \mathrm{nmol} \mathrm{mol}^{-1}\right)$. Using the methods of [45] to determine "pure" stratospheric $\mathrm{O}_{3}$ (see Section 2.4) which separates $\mathrm{O}_{3}$ values associated with photochemically generated tropospheric values (applying model-predicted PVU and $\mathrm{O}_{3}: \mathrm{PV}$ ratios) and those strictly contributed from stratospheric intrusions, it was determined this contribution from long-range/stratospheric sources was likely primarily from the long-range transport of tropospheric $\mathrm{O}_{3}$ and precursor species as model-predicted stratospheric $\mathrm{O}_{3}$ at 08 UTC on 12 June 2013 was predicted to only be "pure" above $\sim 9 \mathrm{~km}$. 
Wildfires are a major source of $\mathrm{NO}_{\mathrm{x}}$ and VOCs and thus have substantial impact on $\mathrm{O}_{3}$ enhancement events (e.g., [49]). GEOS-Chem simulated large $\mathrm{O}_{3}$ mixing ratios due to wildfire emissions, especially at 08 UTC (see Figure 5e) on 12 June 2013. From Table 2 it can be seen that wildfire emissions on average contribute $\sim 2 \mathrm{nmol} \mathrm{mol}^{-1}$ of $\mathrm{O}_{3}(\sim 6 \%$ of total) below $1 \mathrm{~km}$ in June 2013 . During the large nocturnal $\mathrm{O}_{3}$ enhancement measured by TOLNet the model predicts a contribution of $\sim 11 \mathrm{nmol} \mathrm{mol}^{-1}$ (ranging from 10 to $20 \mathrm{nmol} \mathrm{mol}^{-1}$ ) which is $\sim 23 \%$ of total $\mathrm{O}_{3}$. This clearly demonstrates that the model predicts an enhancement from wildfire emissions occurring in the southeast US during this time period. Simple back-trajectories simulated using the Hybrid Single Particle Lagrangian Integrated Trajectory (HYSPLIT) model driven with $12 \mathrm{~km}$ North American Mesoscale Forecast System (NAM) meteorological data are shown in Figure 7a. These trajectory calculations were initiated at 08 UTC on 12 June 2013 at vertical heights of 500, 2000, and $5000 \mathrm{~m}$ above ground level and run backwards in time for $48 \mathrm{~h}$. From this figure it is clear that minimal vertical mixing occurred in the air mass of the lowest layer (parcel started at $500 \mathrm{~m}$ above ground level) and remains near the surface as it was transported over the areas of active burning in Mississippi, Arkansas, and Louisiana observed by the $4 \mathrm{~km}$ Geostationary Operational Environmental Satellite (GOES) fire detection data on 12 June 2013 (see Figure 7b). The backtrajectories for air parcels initiated in the PBL calculated by HYSPLIT are in agreement with Weather Research and Forecasting FLEXible PARTicle (WRF-FLEXPART) dispersion model backtrajectories calculated for SENEX flights [50] occurring later in the day on 12 June 2013. Furthermore, GEOS-Chem predicted elevated mixing ratios of CO below $2 \mathrm{~km}$ between 00 and 08 UTC (7pm-03am CDT) on 12 June 2013 over the UAH TOLNet station and upwind over the region of large fire activity (see Figure 7c). Finally, P3 airborne measurements on the afternoon of 12 June 2013 indicate elevated CO and BC concentrations aloft. Measured CO concentrations above the surface reached values $>200 \mathrm{nmol} \mathrm{mol}^{-1}$ and $\mathrm{BC}$ concentrations were highly variable and reached values between 400 and $500 \mathrm{ng} \cdot \mathrm{m}^{-3}$ which is nearly a factor of 2 larger compared to averaged surface-level concentrations measured by IMPROVE sites in the southeast US during the summer of 2013 [51].

a)

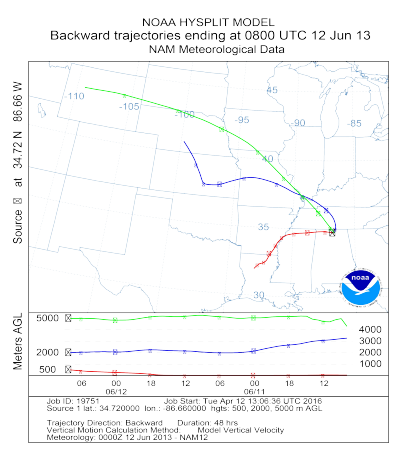

b)

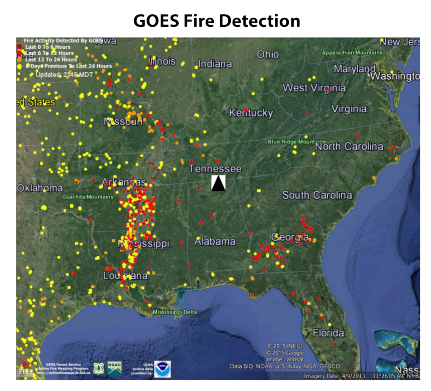

c)

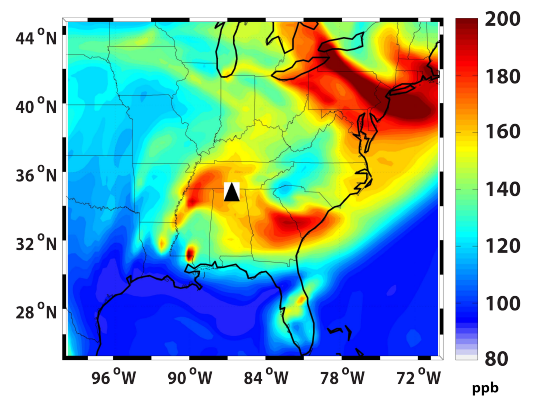

Figure 7. Information supporting the influence of wildfire emissions from (a) HYSPLIT back-trajectories initiated at 08 UTC (starting heights of 500 (red), 2000 (blue), and 5000 (green) m above ground level); (b) GOES fire detection data (red, yellow, and orange dots indicate fire activity observed in last 0-6, 6-12, 12-24 h, respectively); and (c) CO mixing ratios (<2 km) predicted by GEOS-Chem between 00 and 08 UTC.

\subsubsection{June 2013}

TOLNet observations on 29 June 2013 captured a large $\mathrm{O}_{3}$ enhancement layer from 3 to $6 \mathrm{~km}$ above ground level between 01 and 05 UTC. To determine the emission sources and transport processes contributing to the enhancement measured by TOLNet on 29 June 2013, "brute force" sensitivity simulations were conducted. From Figure $5 \mathrm{~d}$, $\mathrm{f}$ it is shown that long-range/stratospheric transport likely had a significant impact on the $\mathrm{O}_{3}$ enhancement measured by TOLNet on 29 June 2013 between 01 and 05 UTC from 3 to $6 \mathrm{~km}$. From Table 2 it can be seen that long-range/stratospheric transport was 
predicted by the model to be larger on 29 June 2013, and during the time of largest $\mathrm{O}_{3}$ enhancement at 03 UTC, compared to monthly-averaged values. During the time of largest observed enhancements, the model predicts long-range/stratospheric transport to contribute $>20 \mathrm{nmol} \mathrm{mol}^{-1}$ more $_{3}$ compared to average conditions. While long-range/stratospheric transport is typically contributing the majority of $\mathrm{O}_{3}$ between 3-6 km over the UAH TOLNet site ( 78\% on average), at 03 UTC on 29 June 2013 long-range/stratospheric transport contributed $>90 \%$ of total $\mathrm{O}_{3}$ in the enhancement layer.

Figure $6 c$,e show the contribution of just stratospheric $\mathrm{O}_{3}$ to total long-range transport $\mathrm{O}_{3}$ for 29 June 2013 and at 03 UTC on this day. From this figure it is shown that stratospheric transport was potentially contributing largely to the enhancement layer at 03 UTC compared to monthly-averages. Using GEOS-5 PVU values it is estimated that between 3-6 km stratospheric transport contributed up to $60 \mathrm{nmol} \mathrm{mol}^{-1}$ of $\mathrm{O}_{3}$ and was up to $\sim 100 \%$ of total long-range transport $\mathrm{O}_{3}$ between 3 and $5 \mathrm{~km}$ with less influence between 5 and $6 \mathrm{~km}$. Applying the methods of [45] to determine "pure" stratospheric $\mathrm{O}_{3}$, it was determined that the stratospheric $\mathrm{O}_{3}$ between 2 and $5 \mathrm{~km}$ was "pure" at this time, thus likely associated with a stratospheric intrusion. Figure 8 shows airborne measurements of $\mathrm{O}_{3}$ and relative humidity (RH) during P3 flights and GEOS-Chem-predicted $\mathrm{O}_{3}$ values. These airborne measurements were taken during P3 flights which occurred later in the day on 29 June 2013 in close proximity (just downwind) of the UAH TOLNet site and this measurement data captured the large $\mathrm{O}_{3}$ lamina between 3 and $6 \mathrm{~km}$. Furthermore, the measurement data shows that the large $\mathrm{O}_{3}$ values were occurring in a very dry $(\mathrm{RH}<5 \%)$ air mass with $\mathrm{CO}$ mixing ratios $<100 \mathrm{nmol} \mathrm{mol}^{-1}$ indicating the influence of stratospheric air. The P3 measurement data agrees with GEOS-5 model predictions at 03 UTC of PVU and RH values which indicate PVU values $>1.0$ co-located with RH values $<15 \%$ between 3 and $6 \mathrm{~km}$ (see Figure 8c). In addition to model and measurement results from this study, Global Forecast System (GFS)-FLEXPART simulations conducted to support the SENEX campaign also suggest that enhanced stratospheric $\mathrm{O}_{3}$ occurred on 29 June 2013 between 3 and $6 \mathrm{~km}$ [52].
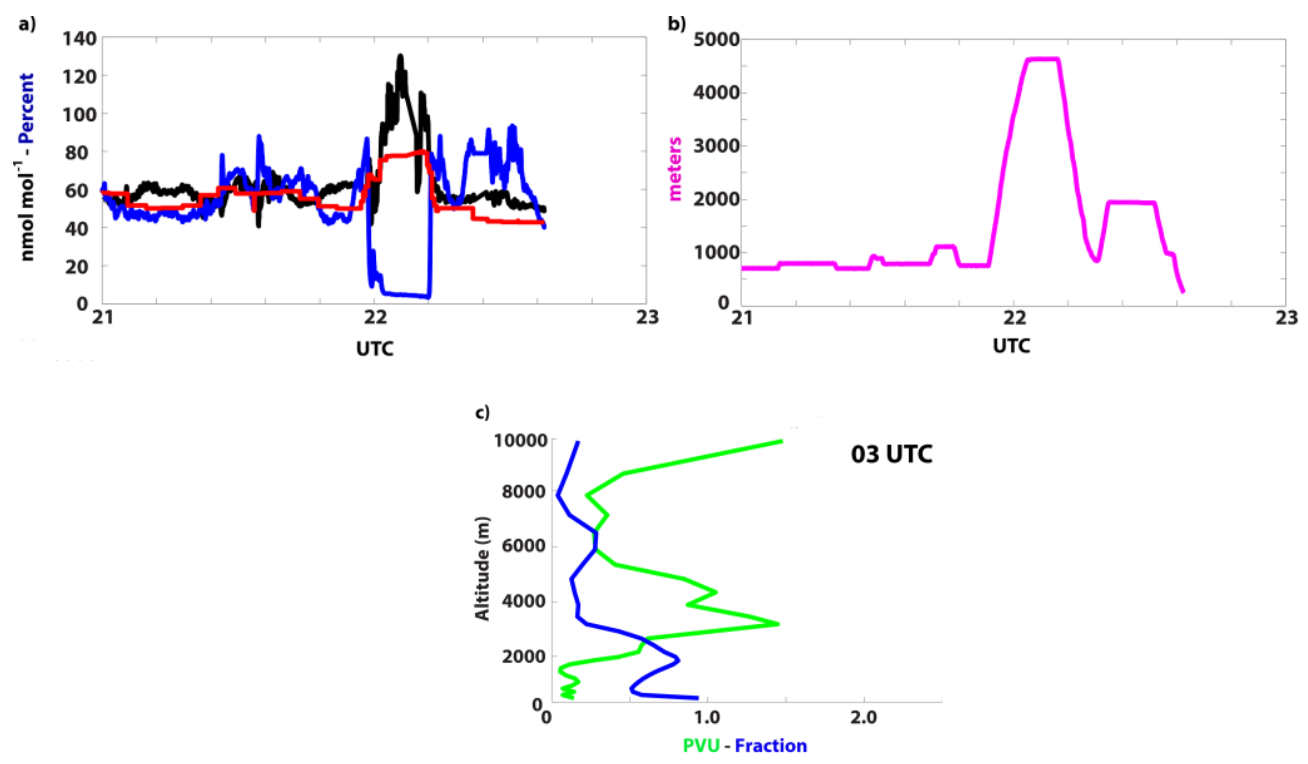

Figure 8. Information supporting the influence of stratospheric air on tropospheric $\mathrm{O}_{3}$ on 29 June 2013 from (a) $\mathrm{P} 3$ measured $\mathrm{O}_{3}$ (black line, nmol mol${ }^{-1}$ ), $\mathrm{RH}$ (blue line, \%), and GEOS-Chem-predicted $\mathrm{O}_{3}$ (red line, $\mathrm{nmol} \mathrm{mol}^{-1}$ ); (b) P3 measured altitude (meters); and (c) GEOS-5 simulated PVU (green line, PVU) and RH (blue line, fraction) at 03 UTC.

\section{Conclusions}

As the EPA implements legislation which reduces NAAQS values for surface $\mathrm{O}_{3}$, it becomes increasingly important to understand the emission sources of precursor species, transport pathways, and chemical processes resulting in elevated $\mathrm{O}_{3}$ mixing ratios. During this study, we apply TOLNet 
lidar observations, surface and airborne in situ data, and model simulations to better understand the emission sources and transport processes impacting $\mathrm{O}_{3}$ mixing ratios in the southeast US. This study focuses on $\mathrm{O}_{3}$ enhancement lamina measured by the UAH TOLNet lidar system during June 2013. This location is representative of southeast US air quality as it is impacted by numerous anthropogenic and natural emission sources of precursor species (e.g., fossil fuel combustion, vehicles, wildfires, lightning, soils, vegetation, etc.) and transport pathways (e.g., local, long-range/inter-continental, stratospheric, etc.). To identify and quantify the sources impacting $\mathrm{O}_{3}$ enhancement lamina measured by the UAH TOLNet, we apply baseline GEOS-Chem model simulations and "brute force" sensitivity simulations during June 2013. This study focused on two case studies: (1) a nocturnal $\mathrm{O}_{3}$ enhancement layer near the surface on 12 June 2013 and (2) a large $\mathrm{O}_{3}$ enhancement layer between $\sim 3$ and $6 \mathrm{~km}$ on 29 June 2013. These two events provided a unique opportunity to study sources and transport processes which impact $\mathrm{O}_{3}$ enhancements in the southeast US at different times and vertical locations in the troposphere.

To determine the ability of GEOS-Chem to capture the mixing ratios of $\mathrm{O}_{3}$ and precursor species in the southeast US, the model was evaluated using SEARCH and EPA AQS surface in situ data and airborne measurements from P3 flights conducted during SENEX. Evaluating the model with surface measurement data of $\mathrm{O}_{3}$ demonstrated that the model had relatively good correlations ( $\mathrm{R}=0.39$ to 0.61 ) and a consistent high bias ( $\mathrm{NMB}=25.5 \%$ to $37.1 \%$ ) compared to observations. Time-series analysis indicated that the model over-prediction was primarily occurring during night-time hours near the surface. The model proved to be able to reproduce $\mathrm{O}_{3}$ mixing ratios measured during P3 flights on 12 and 29 June 2013 above the surface in varying location of the southeast US. During both flights the model captured the magnitudes ( $\mathrm{NMB}=-10 \%$ to $2.1 \%$ ) and spatio-temporal variability of measured $\mathrm{O}_{3}(\mathrm{R}=0.37$ to 0.78$)$. Ozone precursors species $\left(\mathrm{CO}, \mathrm{NO}_{\mathrm{x}}\right.$, and ISOP) predicted by GEOS-Chem were also evaluated using P3 measurements during flights on 12 and 29 June 2013. During these flights the model demonstrated the general ability to replicate measurements of $\mathrm{CO}, \mathrm{NO}_{\mathrm{x}}$, and ISOP over the southeast US. Overall, the model compared moderately well with ground-based measurements and had better agreement with airborne in situ data which provided confidence this model could be applied for estimating source apportionment of the $\mathrm{O}_{3}$ measured by the UAH TOLNet.

Sensitivity simulations were conducted for the entire month of June 2013 and for the two case studies on 12 and 29 June 2013 to quantify $\mathrm{O}_{3}$ production due to North American anthropogenic emissions, wildfires, lightning $\mathrm{NO}_{\mathrm{x}}$, and long-range/stratospheric transport. Monthly-averaged $\mathrm{O}_{3}$ source attribution demonstrated in this study shows that on average near the surface $(<2 \mathrm{~km})$ anthropogenic emissions and long-range/stratospheric $\mathrm{O}_{3}$ make up the majority of model predicted $\mathrm{O}_{3}$. Monthly-averaged source attribution of total $\mathrm{O}_{3}$ aloft $(>3 \mathrm{~km})$ is predominantly contributed from long-range/stratospheric transport, lightning $\mathrm{NO}_{x}$, and anthropogenic emissions.

During the time periods of the two case studies, noticeable differences in $\mathrm{O}_{3}$ source attribution were predicted compared to monthly-averaged values. On 12 June 2013 the near-surface $\mathrm{O}_{3}$ enhancement measured by TOLNet between 02 and 08 UTC, was predicted by the model to have large impact from wildfire emissions with values reaching $>15 \mathrm{nmol} \mathrm{mol}^{-1}$ (below $1.5 \mathrm{~km}$ ). HYSPLIT back-trajectories, GOES fire detection data, and P3 airborne measurement data evaluated during this study further indicate that wildfire emission were likely impacting near-surface air quality and $\mathrm{O}_{3}$ mixing ratios within this $\mathrm{O}_{3}$ enhancement layer. Furthermore, the model predicted that anthropogenic emissions had daily maximum contribution $\left(>15 \mathrm{nmol} \mathrm{mol}^{-1}\right)$ during these night-time hours. When evaluating GEOS-5 meteorological data it is suggested that a weak LLJ could have contributed to this nocturnal enhancement of anthropogenic impact. When evaluating model-predicted source attribution during the case study for the elevated (3-6 km) $\mathrm{O}_{3}$ lamina on 29 June 2013 between 01 and 05 UTC, it was determined that long-range/stratospheric sources were the major contributor to this enhancement. Separating stratospheric sources from total long-range transport $\mathrm{O}_{3}$ and applying methods to calculate "pure" stratospheric air suggests that the majority of the $\mathrm{O}_{3}$ enhancement on this day was from a stratospheric intrusion occurring in the southeast US. Measurement data from a 
P3 flight on 29 June 2013 agree with the model-predicted source attribution from this study, clearly indicating that the $\mathrm{O}_{3}$ lamina between 3 and $6 \mathrm{~km}$ was associated with very dry $(\mathrm{RH}<5 \%)$ and clean $\left(\mathrm{CO}<100 \mathrm{nmol} \mathrm{mol}^{-1}\right)$ air associated with a stratospheric intrusion.

This study emphasizes the fact that numerous emission sources and transport pathways control tropospheric $\mathrm{O}_{3}$ in the southeast US during the summer. In particular it is shown that there is large variability in the magnitude and source attribution of $\mathrm{O}_{3}$ throughout the vertical extent of the troposphere. Finally, in order to better understand emission sources, transport processes, and chemical reactions that control the source attribution of $\mathrm{O}_{3}$ in different vertical levels of the troposphere, it is important to apply numerous sources of measurement data (e.g., surface-based and airborne), remote-sensing observations (e.g., ground-based lidar profiles), and model simulations.

Supplementary Materials: The following are available online at www.mdpi.com/2073-4433/7/8/108/s1. Figure S1: Flight tracks of NOAA P3 measurements during the SENEX field campaign on (a) 12 June 2013 and (b) 29 June 2013 overlaid on Google Earth; Figure S2: GEOS-Chem-predicted monthly-averaged $\mathrm{O}_{3}$ (black line, nmol mol${ }^{-1}$ ), summation of source attributed $\mathrm{O}_{3}$ (red line, nmol mol${ }^{-1}$ ), and the percent difference between baseline and summation of source attributed $\mathrm{O}_{3}$ (blue line, \%) over the UAH TOLNet site during June 2013.

Acknowledgments: This work is supported by the TOLNet program developed by NASA's Science Mission Directorate. Matthew Johnson would also like to thank Daniel Jacob, Katie Travis, and the Harvard University Atmospheric Chemistry Modeling Group for providing the base model GEOS-Chem used during our research. We would also like to thank the SENEX science, instrument, and aircraft teams, with particular thanks to Ilana Pollack and Thomas Ryerson $\left(\mathrm{O}_{3}, \mathrm{NO}_{\mathrm{x}}\right)$, Joshua Schwarz (BC), John S. Holloway (CO), and Martin Graus (Isoprene) for specific trace gas and aerosol data. Resources supporting this work were provided by the NASA High-End Computing (HEC) Program through the NASA Advanced Supercomputing (NAS) Division at NASA Ames Research Center. All the authors express gratitude to the support from NASA's Earth Science Division at Ames Research Center. Finally, the views, opinions, and findings contained in this report are those of the authors and should not be construed as an official NASA or United States Government position, policy, or decision.

Author Contributions: Matthew S. Johnson and Michael J. Newchurch conceived the overall research topic and obtained funding to support the work. Data sources, materials, and evaluation techniques used during the study were developed by Matthew S. Johnson, Shi Kuang, and Lihua Wang. All model simulations and data evaluation were performed by Matthew S. Johnson. Matthew S. Johnson wrote the manuscript with the assistance of significant editorial and scientific improvements from all authors of the manuscript.

Conflicts of Interest: The authors declare no conflict of interest.

\section{References}

1. U.S. Environmental Protection Agency. Air Quality Criteria for Ozone and Related Photochemical Oxidants (2006 Final); EPA/600/R-05/004aF-cF; U.S. Environmental Protection Agency: Washington, DC, USA, 2006.

2. Worden, H.M.; Bowman, K.W.; Worden, J.R.; Eldering, A.; Beer, R. Satellite measurements of the clear-sky greenhouse effect from tropospheric ozone. Nat. Geosci. 2008, 1, 305-308. [CrossRef]

3. U.S. Environmental Protection Agency. National Ambient Air Quality Standards for Ozone-Final Rule; Federal Register 80; U.S. Environmental Protection Agency: Washington, DC, USA, 2015.

4. Fiore, A.M.; Jacob, D.J.; Liu, H.; Yantosca, R.M.; Fairlie, T.D.; Li, Q. Variability in surface ozone background over the United States: Implications for air quality policy. J. Geophys. Res. Atmos. 2003. [CrossRef]

5. Vingarzan, R. A review of surface ozone background levels and trends. Atmos. Environ. 2004, 38, 3431-3442. [CrossRef]

6. Lefohn, A.S.; Wernli, H.; Shadwick, D.; Limbach, S.; Oltmans, S.J.; Shapiro, M. The importance of stratospheric-tropospheric transport in affecting surface ozone concentrations in the western and northern tier of the United States. Atmos. Environ 2011, 45, 4845-4857. [CrossRef]

7. Lin, M.; Fiore, A.M.; Cooper, O.R.; Horowitz, L.W.; Langford, A.O.; Levy, H.; Johnson, B.J.; Naik, V.; Oltmans, S.J.; Senff, C.J. Springtime high surface ozone events over the western United States: Quantifying the role of stratospheric intrusions. J. Geophys. Res. 2012, 117. [CrossRef]

8. Yates, E.L.; Iraci, L.T.; Roby, M.C.; Pierce, R.B.; Johnson, M.S.; Reddy, P.J.; Tadić, J.M.; Loewenstein, M.; Gore, W. Airborne observations and modeling of springtime stratosphere-to-troposphere transport over California. Atmos. Chem. Phys. 2013, 13, 12481-12494. [CrossRef]

9. Zhang, L.; Jacob, D.J.; Yue, X.; Downey, N.V.; Wood, D.A.; Blewitt, D. Sources contributing to background surface ozone in the US Intermountain West. Atmos. Chem. Phys. 2014, 14, 5295-5309. [CrossRef] 
10. Lin, M.; Fiore, A.M.; Horowitz, L.W.; Langford, A.O.; Oltmans, S.J.; Tarasick, D.; Reider, H.E. Climate variability modulates western US ozone air quality in spring via deep stratospheric intrusions. Nat. Commun. 2015, 6. [CrossRef] [PubMed]

11. Hidy, G.M.; Blanchard, C.L.; Baumann, K.; Edgerton, E.; Tanenbaum, S.; Shaw, S.; Knipping, E.; Tombach, I.; Jansen, J.; Walters, J. Chemical climatology of the southeastern United States. Atmos. Chem. Phys. 2014, 14, 11893-11914. [CrossRef]

12. Pfister, G.G.; Emmons, L.K.; Hess, P.G.; Lamarque, J.-F.; Thompson, A.M.; Yorks, J.E. Analysis of the Summer 2004 ozone budget over the United States using Intercontinental Transport Experiment Ozonesonde Network Study (IONS) observations and Model of Ozone and Related Tracers (MOZART-4) simulations. J. Geophys. Res. 2008, 113. [CrossRef]

13. Hudman, R.C.; Murray, L.T.; Jacob, D.J.; Turquety, S.; Wu, S.; Millet, D.B.; Avery, M.; Goldstein, A.H.; Holloway, J. North American influence on tropospheric ozone and the effects of recent emission reductions: Constraints from ICARTT observations. J. Geophys. Res. 2009, 114. [CrossRef]

14. TOLNet-Tropospheric Ozone Lidar Network. Available online: http://www-air.larc.nasa.gov/missions / TOLNet/ (accessed on 15 July 2015).

15. Kuang, S.; Burris, J.F.; Newchurch, M.J.; Johnson, S.; Long, S. Differential absorption Lidar to measure subhourly variation of tropospheric ozone profiles. IEEE Trans. Geosci. Remote Sens. 2011, 49, 557-571. [CrossRef]

16. Kuang, S.; Newchurch, M.J.; Burris, J.; Liu, X. Ground-based Lidar for atmospheric boundary layer ozone measurements. Appl. Opt. 2013, 52, 3557-3566. [CrossRef] [PubMed]

17. Kuang, S.; Newchurch, M.J.; Burris, J.; Wang, L.; Buckley, P.; Johnson, S.; Knupp, K.; Huang, G.; Phillips, D. Nocturnal ozone enhancement in the lower troposphere observed by Lidar. Atmos. Environ. 2011, 45, 6078-6084. [CrossRef]

18. Kuang, S.; Newchurch, M.J.; Burris, J.; Wang, L.; Knupp, K.; Huang, G. Stratosphere-to-troposphere transport revealed by ground-based Lidar and ozonesonde at a midlatitude site. J. Geophys. Res. 2012, 117. [CrossRef]

19. Wang, L.; Follette-Cook, M.; Newchurch, M.; Pickering, K.; Pour-Biazar, A.; Kuang, S.; Koshak, W.; Peterson, H. Evaluation of lightning-induced tropospheric ozone enhancements observed by ozone Lidar and simulated by WRF/Chem. Atmos. Environ. 2015, 115, 185-191. [CrossRef]

20. SouthEastern Aerosol Research and Characterization (SEARCH) Network. Available online: http://www. atmospheric-research.com/studies/SEARCH/ (accessed on 20 September 2015).

21. Environmental Protection Agency-AirData. Available online: https://www3.epa.gov/airquality/airdata/ (accessed on 20 September 2015).

22. Earth System Research Laboratory-Chemical Sciences Division-SENEX Data. Available online: http: //www.esrl.noaa.gov/csd/groups/csd7/measurements/2013senex/ (accessed on 13 January 2016).

23. Bey, I.; Jacob, D.J.; Yantosca, R.M.; Logan, J.A.; Field, B.; Fiore, A.M.; Li, Q.; Liu, H.; Mickley, L.J.; Schultz, M. Global modeling of tropospheric chemistry with assimilated meteorology: Model description and evaluation. J. Geophys. Res. 2001, 106, 23073-23095. [CrossRef]

24. Lin, S.J.; Rood, R.B. Multidimensional flux form semi-Lagrangian transport schemes. Mon. Weather Rev. 1996, 124, 2046-2070. [CrossRef]

25. Lin, J.-T.; McElroy, M. Impacts of boundary layer mixing on pollutant vertical profiles in the lower troposphere: Implications to satellite remote sensing. Atmos. Environ. 2010, 44, 1726-1739. [CrossRef]

26. Liu, H.; Jacob, D.J.; Bey, I.; Yantosca, R.M. Constraints from $210 \mathrm{~Pb}$ and $7 \mathrm{Be}$ on wet deposition and transport in a global three dimensional chemical tracer model driven by assimilated meteorological fields. J. Geophys. Res. 2001, 106, 12109-12128. [CrossRef]

27. Amos, H.M.; Jacob, D.J.; Holmes, C.D.; Fisher, J.A.; Wang, Q.; Yantosca, R.M.; Corbitt, E.S.; Galarneau, E.; Rutter, A.P.; Gustin, M.S.; et al. Gas-Particle partitioning of atmospheric $\mathrm{Hg}(\mathrm{II})$ and its effect on global mercury deposition. Atmos. Chem. Phys. 2012, 12, 591-603. [CrossRef]

28. Wang, Y.H.; Jacob, D.J.; Logan, J.A. Global simulation of tropospheric $\mathrm{O}_{3}-\mathrm{NO}_{\mathrm{x}}$-hydrocarbon chemistry: 1. Model formulation. J. Geophys. Res. 1998, 103, 10713-10725. [CrossRef]

29. Travis, K.R.; Jacob, D.J.; Fisher, J.A.; Kim, P.S.; Marais, E.A.; Zhu, L.; Yu, K.; Miller, C.C.; Yantosca, R.M.; Sulprizio, M.P.; et al. $\mathrm{NO}_{\mathrm{x}}$ emissions, isoprene oxidation pathways, vertical mixing, and implications for surface ozone in the Southeast United States. Atmos. Chem. Phys. Discuss. 2016. [CrossRef] 
30. Environmental Protection Agency—Air Pollutant Emissions Trends Data. Available online: https://www. epa.gov / air-emissions-inventories/air-pollutant-emissions-trends-data (accessed on 5 August 2015).

31. Fujita, E.M.; Campbell, D.E.; Zielinska, B.; Chow, J.C.; Lindhjem, C.E.; DenBleyker, A.; Bishop, G.A.; Schuchmann, B.G.; Stedman, D.H.; Lawson, D.R. Comparison of the MOVES2010a, MOBILE6.2, and EMFAC2007 mobile source emission models with on-road traffic tunnel and remote sensing measurements. J. Air Waste Manag. Assoc. 2012, 62, 1134-1149. [CrossRef] [PubMed]

32. Brioude, J.; Angevine, W.M.; Ahmadov, R.; Kim, S.W.; Evan, S.; McKeen, S.A.; Hsie, E.Y.; Frost, G.J.; Neuman, J.A.; Pollack, I.B.; et al. Top-down estimate of surface flux in the Los Angeles Basin using a mesoscale inverse modeling technique: assessing anthropogenic emissions of $\mathrm{CO}, \mathrm{NO}_{\mathrm{x}}$ and $\mathrm{CO}_{2}$ and their impacts. Atmos. Chem. Phys. 2013, 13, 3661-3677. [CrossRef]

33. Anderson, D.C.; Loughner, C.P.; Diskin, G.; Weinheimer, A.; Canty, T.P.; Salawitch, R.J.; Worden, H.M.; Fried, A.; Mikoviny, T.; Wisthaler, A.; et al. Measured and modeled CO and $\mathrm{NO}_{\mathrm{y}}$ in DISCOVER-AQ: An evaluation of emissions and chemistry over the eastern US. Atmos. Environ. 2014, 96, 78-87. [CrossRef]

34. Canty, T.P.; Hembeck, L.; Vinciguerra, T.P.; Anderson, D.C.; Goldberg, D.L.; Carpenter, S.F.; Allen, D.J.; Loughner, C.P.; Salawitch, R.J.; et al. Ozone and $\mathrm{NO}_{\mathrm{x}}$ chemistry in the eastern US: Evaluation of CMAQ/CB05 with satellite (OMI) data. Atmos. Chem. Phys. 2015, 15, 10965-10982. [CrossRef]

35. Darmenov, A.S.; da Silva, A. The Quick Fire Emissions Dataset (QFED): Documentation of Versions 2.1, 2.2 and 2.4. Available online: https://gmao.gsfc.nasa.gov/pubs/docs/Darmenov796.pdf (accessed on 19 August 2016).

36. Murray, L.T.; Jacob, D.J.; Logan, J.A.; Hudman, R.C.; Koshak, W.J. Optimized regional and interannual variability of lightning in a global chemical transport model constrained by LIS/OTD satellite data. J. Geophys. Res. 2012, 117. [CrossRef]

37. Hudman, R.C.; Jacob, D.J.; Turquety, S.; Leibensperger, E.M.; Murray, L.T.; Wu, S.; Gilliland, A.B.; Avery, M.; Bertram, T.H.; Brune, W.; et al. Surface and lightning sources of nitrogen oxides over the United States: Magnitudes, chemical evolution, and outflow. J. Geophys. Res. 2007, 112. [CrossRef]

38. McLinden, C.A.; Olsen, S.C.; Hannegan, B.; Wild, O.; Prather, M.J.; Sundet, J. Stratospheric ozone in 3-D models: A simple chemistry and the cross-tropopause flux. J. Geophys. Res. 2000, 105, 14653-14665. [CrossRef]

39. Hsu, J.; Prather, M.J.; Wild, O. Diagnosing the stratosphere-to-troposphere flux of ozone in a chemistry transport model. J. Geophys. Res. 2005, 110. [CrossRef]

40. Ott, L.E.; Duncan, B.N.; Thompson, A.M.; Diskin, G.; Fasnacht, Z.; Langford, A.O.; Lin, M.; Molod, A.M.; Nielsen, J.E.; Pusede, S.E.; et al. Frequency and impact of summertime stratospheric intrusions over Maryland during DISCOVER-AQ (2011): New evidence from NASA's GEOS-5 simulations. J. Geophys. Res. Atmos. 2016, 121. [CrossRef]

41. Cohan, D.S.; Napelenok, S.L. Air quality response modeling for decision support. Atmosphere 2011, 2, 407-425. [CrossRef]

42. Kwok, R.H.F.; Baker, K.R.; Napelenok, S.L.; Tonnesen, G.S. Photochemical grid model implementation and application of VOC, $\mathrm{NO}_{x}$, and $\mathrm{O}_{3}$ source apportionment. Geosci. Model Dev. 2015, 8, 99-114. [CrossRef]

43. Stohl, A.; Spichtinger-Rakowsky, N.; Bonasoni, P.; Feldmann, H.; Memmesheimer, M.; Scheel, H.E.; Trickl, T.; Hübener, S.; Ringer, W.; Mandl, M. The influence of stratospheric intrusions on Alpine ozone concentrations. Atmos. Environ. 2000, 34, 1323-1354. [CrossRef]

44. Rao, T.N.; Kirkwood, S.; Arvelius, J.; Von der Gathen, P.; Kivi, R. Climatology of UTLS ozone and the ratio of ozone and potential vorticity over northern Europe. J. Geophys. Res. 2003, 108. [CrossRef]

45. Sullivan, J.T.; McGee, T.J.; Thompson, A.M.; Pierce, R.B.; Sumnicht, G.K.; Twigg, L.W.; Eloranta, E.; Hoff, R.M. Characterizing the lifetime and occurrence of stratospheric-tropospheric exchange events in the rocky mountain region using high-resolution ozone measurements. J. Geophys. Res. Atmos. 2015, 120, 12410-12424. [CrossRef]

46. Beekmann, M.; Ancellet, G.; Mégie, G. Climatology of tropospheric ozone in southern Europe and its relation to potential vorticity. J. Geophys. Res. 1994, 99, 12841-12853. [CrossRef]

47. Hoskins, B.J.; McIntyre, M.E.; Robertson, A.W. On the use and significance of isentropic potential vorticity maps. Q. J. R. Meteorol. Soc. 1985, 111, 877-946. [CrossRef]

48. Adamson, D.S.; Belcher, S.E.; Hoskins, B.J.; Plant, R.S. Boundary-layer friction in the midlatitude cyclone. Q. J. R. Meteorol. Soc. 2006, 132, 101-124. [CrossRef] 
49. Jaffe, D.A.; Wigder, N.L. Ozone production from wildfires: A critical review. Atmos. Environ. 2012, 51, 1-10. [CrossRef]

50. Earth System Research Laboratory-Chemical Sciences Division_FLEXPART Backtrajectories. Available online: http:/ / esrl.noaa.gov/csd/groups/csd4/forecasts/backward/ (accessed on 18 November 2015).

51. Kim, P.S.; Jacob, D.J.; Fisher, J.A.; Travis, K.; Yu, K.; Zhu, L.; Yantosca, R.M.; Sulprizio, M.P.; Jimenez, J.L.; Campuzano-Jost, P.; et al. Sources, seasonality, and trends of southeast US aerosol: An integrated analysis of surface, aircraft, and satellite observations with the GEOS-Chem chemical transport model. Atmos. Chem. Phys. 2015, 15, 10411-10433. [CrossRef]

52. Earth System Research Laboratory-Chemical Sciences Division_FLEXPART Forecasts for SENEX 2013. Available online: http:/ / esrl.noaa.gov/csd/groups/csd4/forecasts/senex/ (accessed on 18 November 2015).

(C) 2016 by the authors; licensee MDPI, Basel, Switzerland. This article is an open access article distributed under the terms and conditions of the Creative Commons Attribution (CC-BY) license (http://creativecommons.org/licenses/by/4.0/). 